\title{
LIQUEFACTION-INDUCED GROUND DISPLACEMENT AND ITS RELATED DAMAGE TO LIFELINE FACILITIES
}

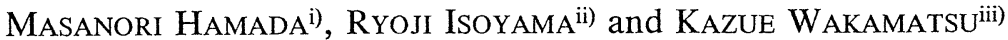

\begin{abstract}
This paper introduces an outline of liquefaction-induced large ground displacement and the damage to lifeline facilities, and foundations of buildings and bridges piles during the 1995 Hyogoken-Nambu earthquake. Some typical examples of large ground displacements which were measured by aerial survey are presented and the causal relationship of damage to buried pipes and foundation piles with ground displacement is introduced. In addition, the present paper outlines the soil and geomorphological conditions in the areas where the liquefaction and the large ground displacements occurred.
\end{abstract}

Key words: case history, decomposed granite soil, earthquake damage, liquefaction, measurement, sandy soil, site investigation (IGC: E8/C1)

\section{INTRODUCTION}

The 1995 Hyogoken-Nambu earthquake caused severe soil liquefaction in extensive areas of reclaimed land in Kobe and its neighboring cities. The soil liquefaction also induced large ground displacements in the horizontal direction, which resulted in serious damage to buried lifeline facilities and foundations of structures. Since liquefaction-induced large ground displacements were first observed from aerial photographs at the time of the 1983 Nihonkai-Chubu earthquake, a collaborative research program has been conducted between the U.S. and Japan in order to investigate the mechanism of the liquefaction-induced large ground displacements and to develop effective countermeasures. The 1995 HyogokenNambu earthquake, however, again induced large ground displacements in large reclaimed land areas, and caused devastating damage to "lifelines" including buried pipelines, and foundations of buildings and bridges.

The authors measured the liquefaction-induced ground displacements in reclaimed land areas along the waterfront of Kobe with an aerial survey using both preand post-earthquake photographs. Maps of the liquefaction-caused ground failures such as fissures and sand boils were also drawn based on interpretation of post-earthquake aerial photos as well as by referring to the results from field surveys. In addition, the soil and geomorphological conditions of the areas where the liquefaction and large ground displacement occurred were investigated by collecting existing borehole logs.

This paper outlines the measured ground displacement, ground failures and the related damage, and a summarizes subsurface conditions. The complete results of the research is reported in Hamada et al. (1995).

\section{SUBSURFACE CONDITIONS}

\section{Geological and Geomorphological settings}

The survey area, which is located at the southern foot of the Rokko Mountains, is approximately $3 \mathrm{~km}$ wide in the north-south direction and $25 \mathrm{~km}$ long in the east-west direction. The Rokko Mountains, with elevations of more than $900 \mathrm{~m}$ in the eastern part and about $400 \mathrm{~m}$ in the western part, are comprised of granite formed by igneous activities in the Cretaceous period. The granite easily weathers and decomposes known as "Masado", which is characterized by low plasticity, low cohesion, high permeability and ease of erosion (JSSMFE ed., 1974).

Many fans have developed along the southern foot the Rokko Mountains. They are composed of coarse granite materials including sand, gravel and boulders.

The area between the fans and south of Route 43 (former shoreline) in Kobe and Ashiya is a relatively flat coastal plain, which simply consists of two geomorphological units, sand bar and back marsh. The area south of Route 43 comprises reclaimed land areas.

i) Professor, The School of Science and Engineering, Waseda University, Ohkubo 3-4-1, Shinjuku-ku, Tokyo 169.

ii) Deputy Director, Earthquake Mitigation Division, Japan Engineering Consultants, Co., Ltd.

iii) Guest Researcher, Advanced Research Center for Science and Engineering, Waseda University.

Manuscript was received for review on August 17, 1995.

Written discussions on this paper should be submitted before August 1, 1996, to the Japanese Geotechnical Society, Sugayama Bldg. 4F, Kanda Awaji-cho 2-23, Chiyoda-ku, Tokyo 101, Japan. Upon request the closing date may be extended one month. 
Reclamation of Kobe Port began extensively in the 1880's. Wharves such as Hyogo wharf and Piers Nos. 1 to 8 were built by 1940 . From 1953, cut and fill projects were undertaken in which mountains and hills including the Rokko Mountains and Awaji Island were systematically excavated and the material was dumped in open water along the shoreline (Miyanaga and Takeyama, 1991). The reclaimed areas include Mikage-hama, Uozaki-hama, Port Island and Rokko Island as shown in Table 1. Similar land reclamation was carried out in the cities of Ashiya and Nishinomiya (the Third Port and Harbor Bureau, Ministry of Transport, 1967; Toyo Corporation, 1987; the Enterprise Agency of Hyogo Prefecture, 1995; the Housing Public Corporation of Hyogo Prefecture, 1995), which are also shown in Table 1.

In the reclaimed areas, soil improvements such as sand drain and pre-loading methods were applied in the areas where major structures were built to accelerate consolidation of the alluvial marine clay. Vibration compaction

d sand compaction pile methods were applied in order densely compact fill as a protective measure against li- quefaction and minimize differential settlement for the bearing layers where structures are supported by spread foundation. The areas where these soil improvements were performed include Port Island, Rokko Island and Minami-Ashiya-hama, second stage of Port Island, Ashiya-hama Seaside Town, Nishinomiya-hama and Koshien-hama (after the Enterprise Agency of Hyogo Prefecture, 1995).

\section{Soil Conditions}

On the basis of existing borehole data (e.g. Kobe City, 1980), 37 sections across reclaimed lands were developed to determine subsurface conditions (Hamada et al., 1995). Typical soil profiles are shown in Fig. 1.

The geology of the reclaimed lands is essentially fill (F) overlying soft Holocene marine clay (Ac) which, in turn, overlies a series of Pleistocene deposits: alternate layers of dense sand and stiff clays (Dsc), stiff clay (Dc) and dense gravel (Dg).

Fill (F) is mainly composed of Masado, excavated from the Rokko Mountains and Awaji Island near the

Table 1. Summary of reclamation in Kobe, Ashiya and Nishinomiya

\begin{tabular}{|c|c|c|c|c|c|}
\hline \multicolumn{2}{|r|}{ Area } & $\begin{array}{l}\text { Project } \\
\text { Organization }\end{array}$ & Work Period & Source of Fill & Geology of Fill \\
\hline \multirow{7}{*}{$\begin{array}{l}\text { First } \\
\text { Stage }\end{array}$} & $\begin{array}{c}\text { Sotohama, } \\
\text { Komagabayashi-minami }\end{array}$ & Kobe City & $1957-1967$ & Suma ward, Kobe & Rokko Granite ${ }^{* 1}$ \\
\hline & Karimojima & ditto & $1963-1968$ & ditto & ditto \\
\hline & Tohya-hama & ditto & $1960-1966$ & Suma ward, Kobe & ditto \\
\hline & Nada-hama-higashi & ditto & $1953-1967$ & Nada ward, Kobe & ditto \\
\hline & $\begin{array}{l}\text { Mikage-hama, } \\
\text { Sumiyoshi-hama }\end{array}$ & ditto & $1960-1968$ & ditto & ditto \\
\hline & Uozaki-hama & ditto & $1961-1968$ & Higashi-Nada ward, Kobe & ditto \\
\hline & Fukae-hama & ditto & $1964-1970$ & Suma ward, Kobe & ditto \\
\hline \multirow{3}{*}{$\begin{array}{l}\text { econd } \\
\text { Stage }\end{array}$} & Port Island & ditto & $1966-1980$ & ditto & ditto \\
\hline & Rokko Island & ditto & $1972-1990$ & $\begin{array}{l}\text { Suma and Nishi wards, } \\
\text { Kobe }\end{array}$ & $\begin{array}{l}\text { Rokko Granite, Kobe Group*2, } \\
\text { Osaka Group*3 }\end{array}$ \\
\hline & Port Island 2nd stage & ditto & $1986-1996$ & Nishi ward, Kobe & Kobe Group, Osaka Group \\
\hline \multicolumn{2}{|c|}{ Maya Wharf } & $\begin{array}{l}\text { Ministry of } \\
\text { Transport }\end{array}$ & $1959-1967$ & $\begin{array}{l}\text { Nada ward, Kobe } \\
\text { Kobe Port }\end{array}$ & $\begin{array}{l}\text { Rokko Granite } \\
\text { Marine Sand }\end{array}$ \\
\hline \multicolumn{2}{|c|}{ Ashiya-hama } & $\begin{array}{l}\text { Hyogo } \\
\text { Prefecture }\end{array}$ & $1969-1975$ & $\begin{array}{l}\text { Okayama Prefecture, } \\
\text { Awaji Island }\end{array}$ & $\begin{array}{l}\text { Marine sand } \\
\text { Ryoke Granite }\end{array}$ \\
\hline \multicolumn{2}{|c|}{ Minami-Ashiya-hama } & $\begin{array}{l}\text { Hyogo } \\
\text { Prefecture }\end{array}$ & 1971-1996 & Awaji Island & Ryoke Granite \\
\hline \multicolumn{2}{|c|}{ Nishinomiya-hama } & $\begin{array}{l}\text { Hyogo } \\
\text { Prefecture }\end{array}$ & 1971-1992 & ditto & ditto \\
\hline \multicolumn{2}{|c|}{ Koshien-hama } & $\begin{array}{l}\text { Hyogo } \\
\text { Prefecture }\end{array}$ & 1971-1994 & ditto & ditto \\
\hline \multicolumn{2}{|c|}{ Naruo-hama } & $\begin{array}{l}\text { Private } \\
\text { Enterprise }\end{array}$ & $1967-1975$ & ditto & ditto \\
\hline
\end{tabular}

*1: Granite including decomposed granite (Late Cretaceous)

*2: Mainly consists of lacustrine mudstone, sandstone, and conglomerate embedded with intermediate layers of tuff (Miocene)

*3: Mainly consists of marine clay embeded with intermediate layers of gravel and volcanic ash (Early Pleistocene)

*4: Granite including decomposed granite (Early to Late Cretaceous) 

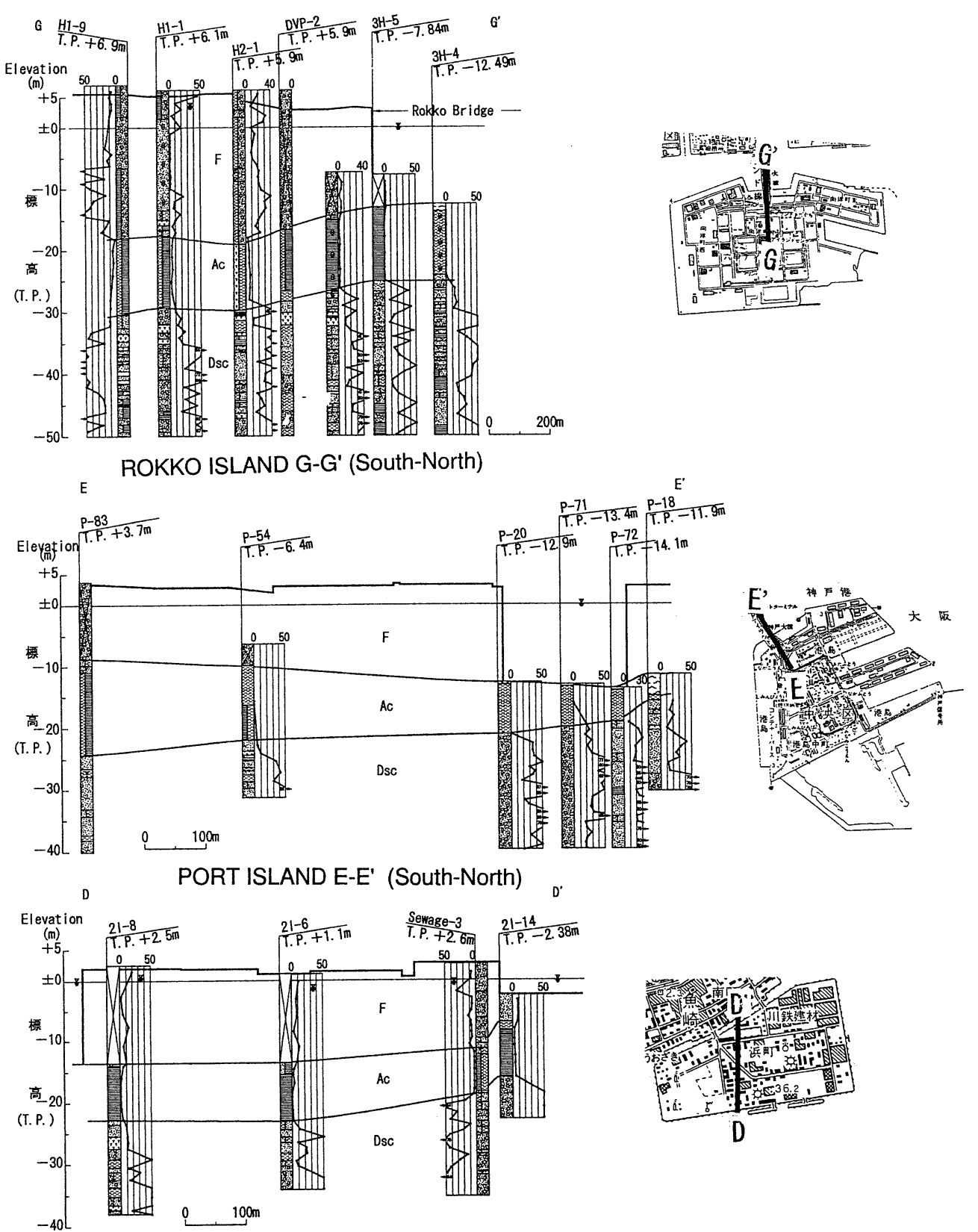

UOZAKI-HAMA D-D' (South-North)
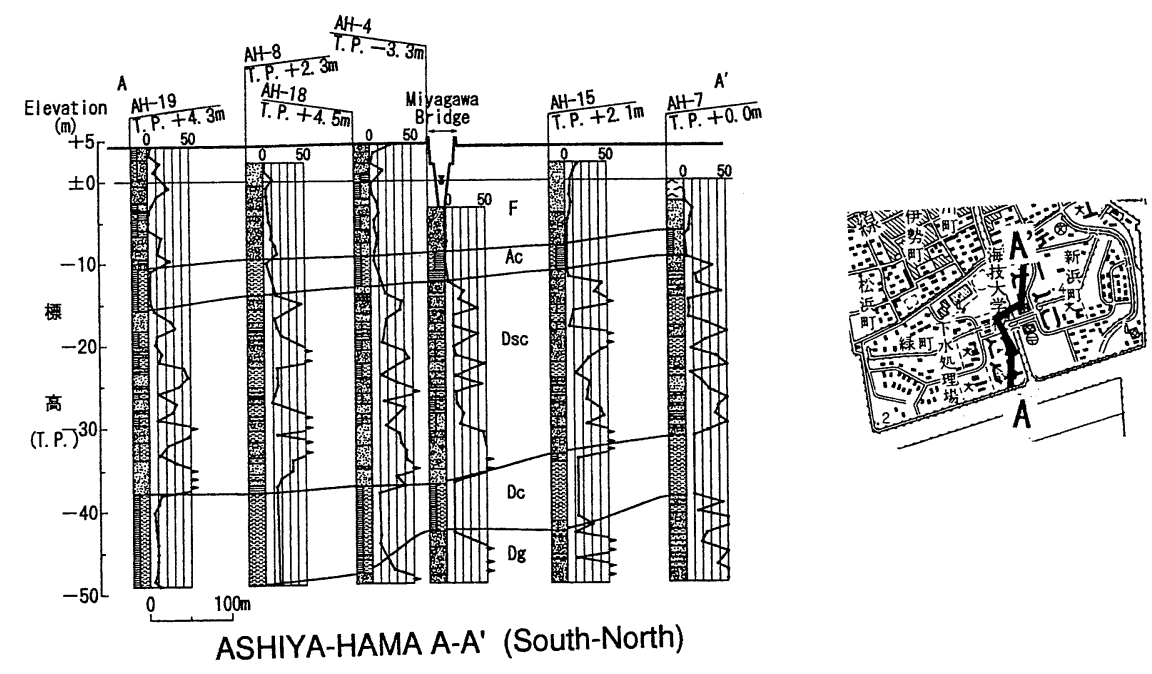

Fig. 1. Typical soil profiles in fill areas 


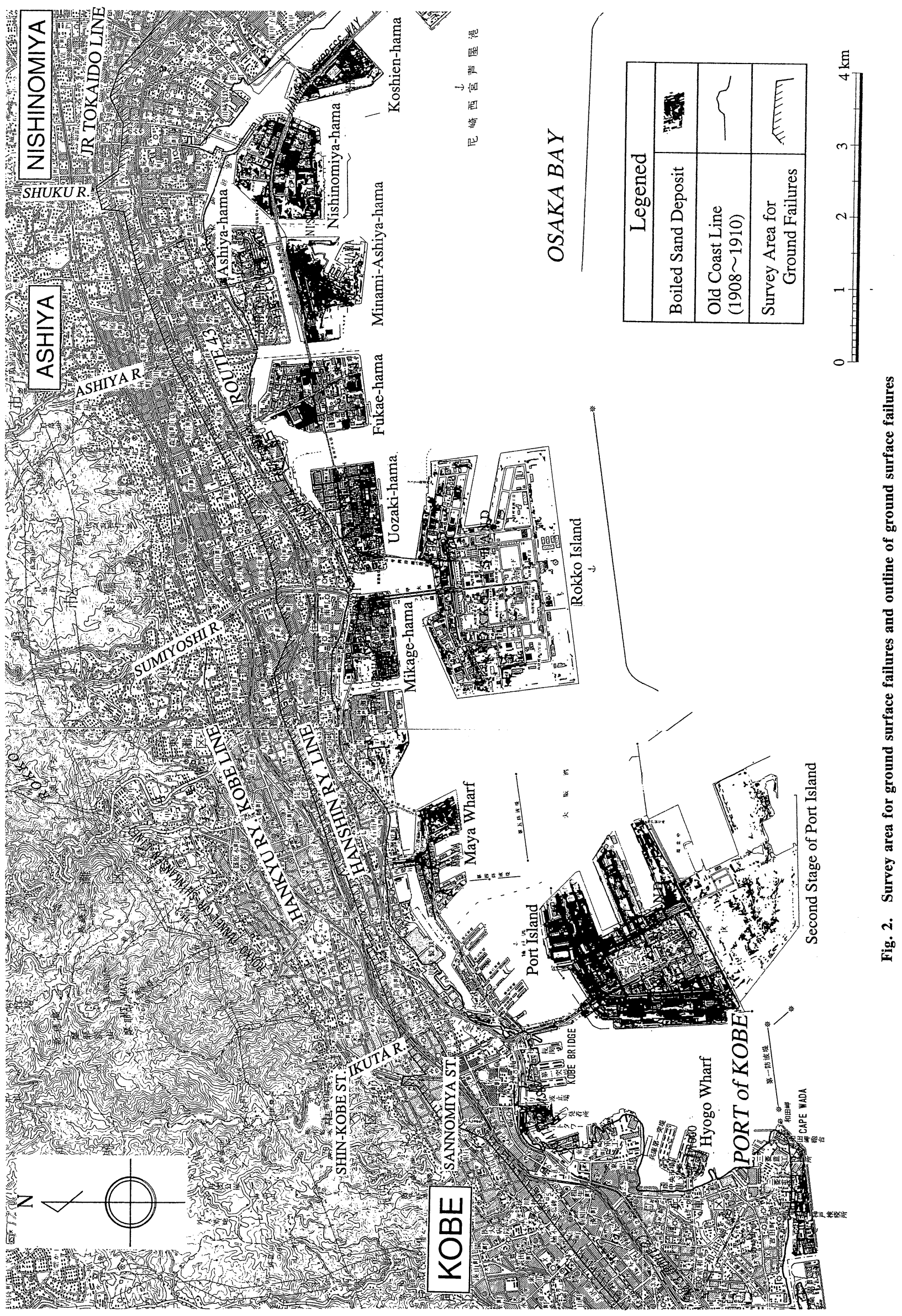


epicenter and Pliocene deposits of mudstone, sandstone and conglomerate of Kobe Group from western Kobe, partially of Pleistocene marine clay and gravel of Osaka Group and dredged sands. The fill also contains rubble and waste from construction sites.

The thickness of the fill in the survey area varies from $5 \mathrm{~m}$ to $25 \mathrm{~m}$. It generally increases offshore. The typical fill soil is sand and gravel with clay containing boulders of diameter $30-60 \mathrm{~cm}$. The diameter of the gravel ranges from 2 to $60 \mathrm{~mm}$ and the sand is mainly Masado of medium to coarse grades. Generally, the SPT $N$-value ranges between 5 and 20 but sometimes exceeds 50 .

\section{Liquefied Layer}

It is impossible to estimate the liquefied layers using the simplified procedures outlined in the Japanese Highway Bridge Code, because the peak accelerations observed during the present earthquake were too large to apply them. The grain size distribution of the soils were also beyond the limits of applicability of them. There is no doubt that fills liquefied during the current earthquake judging from the similarity in grain size distribution and the color of fill and sands ejected. It was not clear, however, as to whether or not all the fills below water level liquefied.

\section{GROUND SURFACE FAILURES}

Identifications of the locations where soil liquefaction occurred were made based on a field survey during past earthquakes. It was impossible, however, to determine the liquefaction areas using such a method, because the region to be investigated was too large and there were many areas that were inaccessible. In the case of such a field survey, there is also the possibility of variations in individual judgment or variations due to the time when the survey was carried out.

The authors identified the locations of failures due to liquefaction based on photographic interpretations and maps of sand boils, sand volcano and fissures were drawn.

The survey was carried out along the coastal region extending from Suma-ku, Kobe City, to the Mukogawa River that forms the borderline between Nishinomiya and Amagasaki cities as shown in Fig. 2.

The aerial photographs used in the photographic interpretation were taken on the following dates, after the earthquake which occurred on January 17, 1995.

(1) January 18, 1995 From Suma-ku to Hyogo-ku in Kobe

(2) January 20, 1995 From Kobe City center to Rokko Island

(3) January 21, 1995 East of Rokko Island

The elevation was about $1,300 \mathrm{~m}$ in the case of photographs (1) and (2), and about $1,800 \mathrm{~m}$ for photographs (3). In all cases, the scale was $1 / 8,500$. A total of around 120 photographs was used in this survey. Typical examples of the aerial photographs are shown in Photo. 1 and
Photogravure 2 from this volume.

The accuracy of the photographic interpretation of ground failures cannot be expressed quantitatively as in the case of aerial photogrammetry. In the case of ground fissures, however, it is believed that cracks of widths exceeding around $15 \mathrm{~cm}$ could be discerned from of the scale of the aerial photographs $(1 / 8,500)$. The accuracy of the displacement of the sea walls fell to around $50 \mathrm{~cm}$ depending on the accuracy of the coordinates of standard control points used in the survey.

Actually, not all cases of surface ground failures have been confirmed by this evaluation of aerial photographs. There are many places that were hidden by trees or elevated roads, and only instances of sand boil that were definitely confirmed were plotted. As a result, there are probably a large number of other locations or areas where liquefaction occurred. At Port Island and at Rokko Island, considerable sand boiled and flowed out, resulting in very wide sand boil deposits on these islands. Although these areas were identified as sand boil areas, it should be noted that this does not necessarily indicate that liquefaction occurred over the entire area.

The results of the photographic interpretation of surface ground failures from the aerial photographs was originally plotted on $1 / 2,500$ scale maps, and they reduced to $1 / 4,000$ scale in Hamada et al. (1995).

Figure 2 shows an outline of the surface ground failures in the entire region surveyed. In this figure, the old coastline based on the topographical maps compiled by the Geographical Survey Institute during 1,908 $\sim 1,910$ s is also shown. It was found that, in general, ground failures occurred in the reclaimed area, and were also extensive in the southern part (new reclaimed area).

The surface ground failures in Port Island, Rokko Island, Uozaki-hama and Ashiya-hama are shown in Figs. 3 to 6 as typical examples.

From a detailed examination of the reclaimed land areas, for example, Port Island and Rokko Island, a difference can be seen in the ground failures occurring according to the area within the island. For both islands, few ground failures occurred in the areas where soil improvement was carried out. On Rokko Island, while extensive disruption occurred on the north side of the island, disruption in the south (except for the area near the sea wall) was considerably less. The probable reason for the less liquefaction effect in the south end of Rokko Island is that the materials used for fill consisted of cohesive soils of the Kobe and Osaka Groups. Other areas including the north end of Rokko Island and Port Island were filled with Granite (Masado) as shown in Table 1. Detailed studies on both the soil and topographical conditions will be required.

Ground failures have also occurred at various points on the northern section of the old coastline as shown in Fig. 2. Future investigations are necessary, including onsite interviews, and studies of the old topography, to determine the causes of the ground failures. 


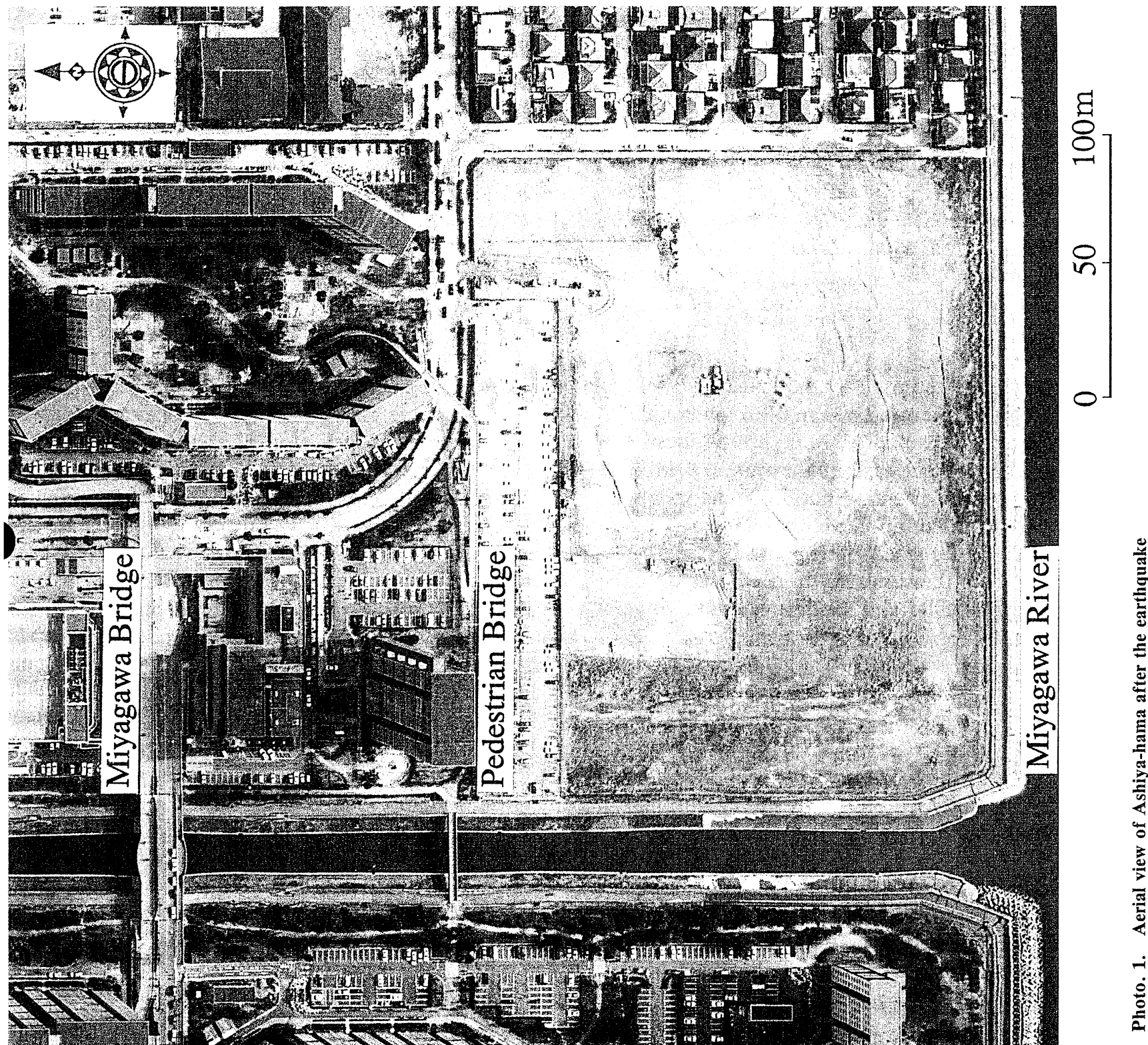




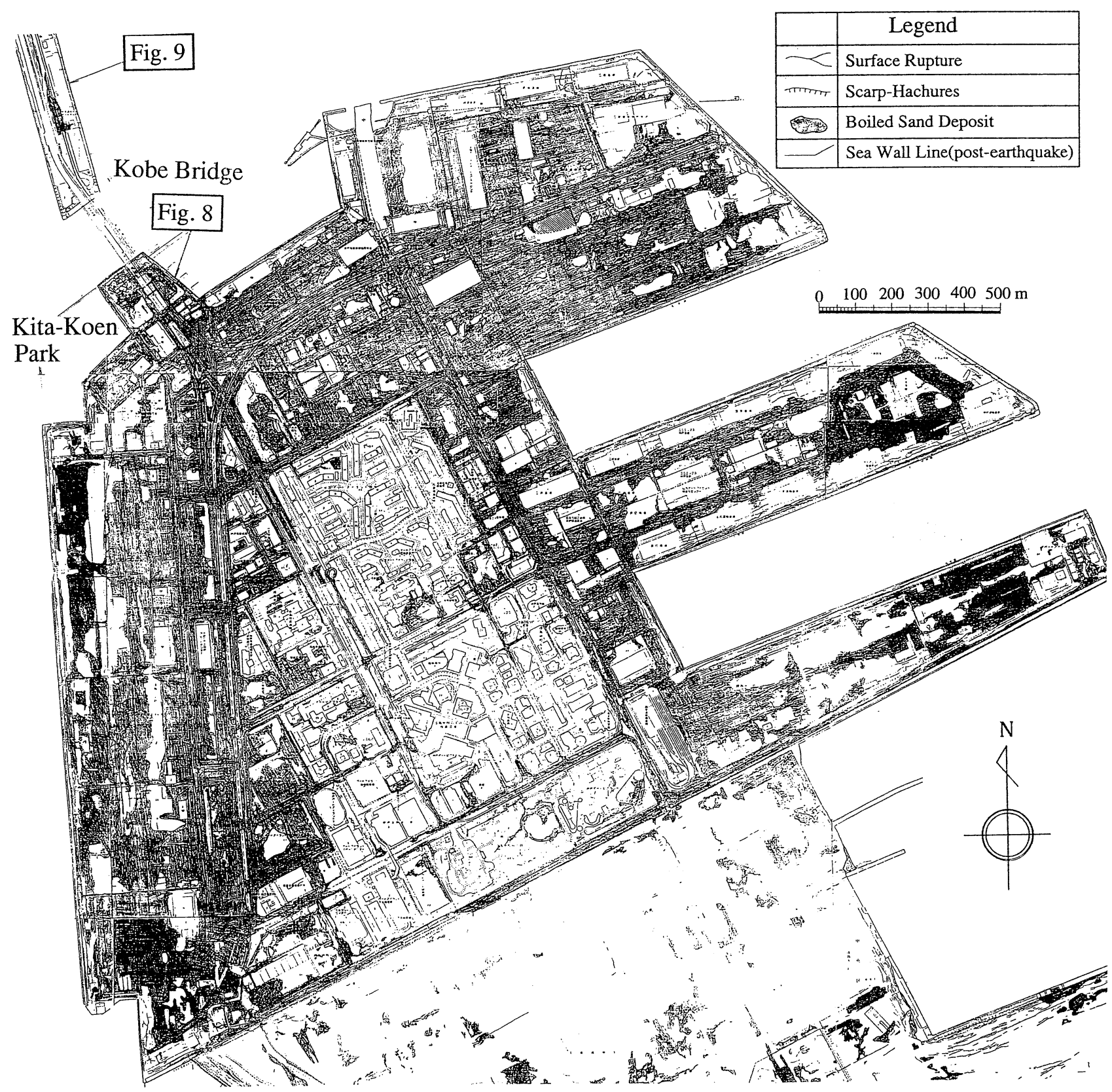

Fig. 3. Ground surface failures in Port Island

\section{LIQUEFACTION-INDUCED GROUND DISPLACEMENT}

\section{Method of Measurement and Accuracy}

Liquefaction-induced ground displacements were measured on the two manmade islands (Port and Rokko Islands), and other reclaimed land areas in Kobe, and the neighboring cities.

Two sets of aerial photographs, which were taken in the same area before and after the earthquake, are necessary for measurement of ground displacements. The following sets of aerial photographs were used for measurement:

$\begin{array}{rll}\text { Pre-earthquake, } & \text { Scale: } & 1 / 12,500 \\ \text { Date: } & \text { May 1990, May } 1993 \text { and } \\ & \text { May 1994 } \\ \text { Post-earthquake, Scale: } & 1 / 8,500, \\ \text { Date: } & \text { Jan. (18th 21st.) } 1995 .\end{array}$

Three dimensional coordinates before as well as after the earthquake were measured of objects fixed on the ground surface such as manholes and corners of drainage channels, and/or of corners of roofs of reportedly undamaged structures. The liquefaction-induced ground displacements were obtained by subtracting coordinates before the earthquake from ones after the earthquake.

The accuracy of each aerial survey before and after the 


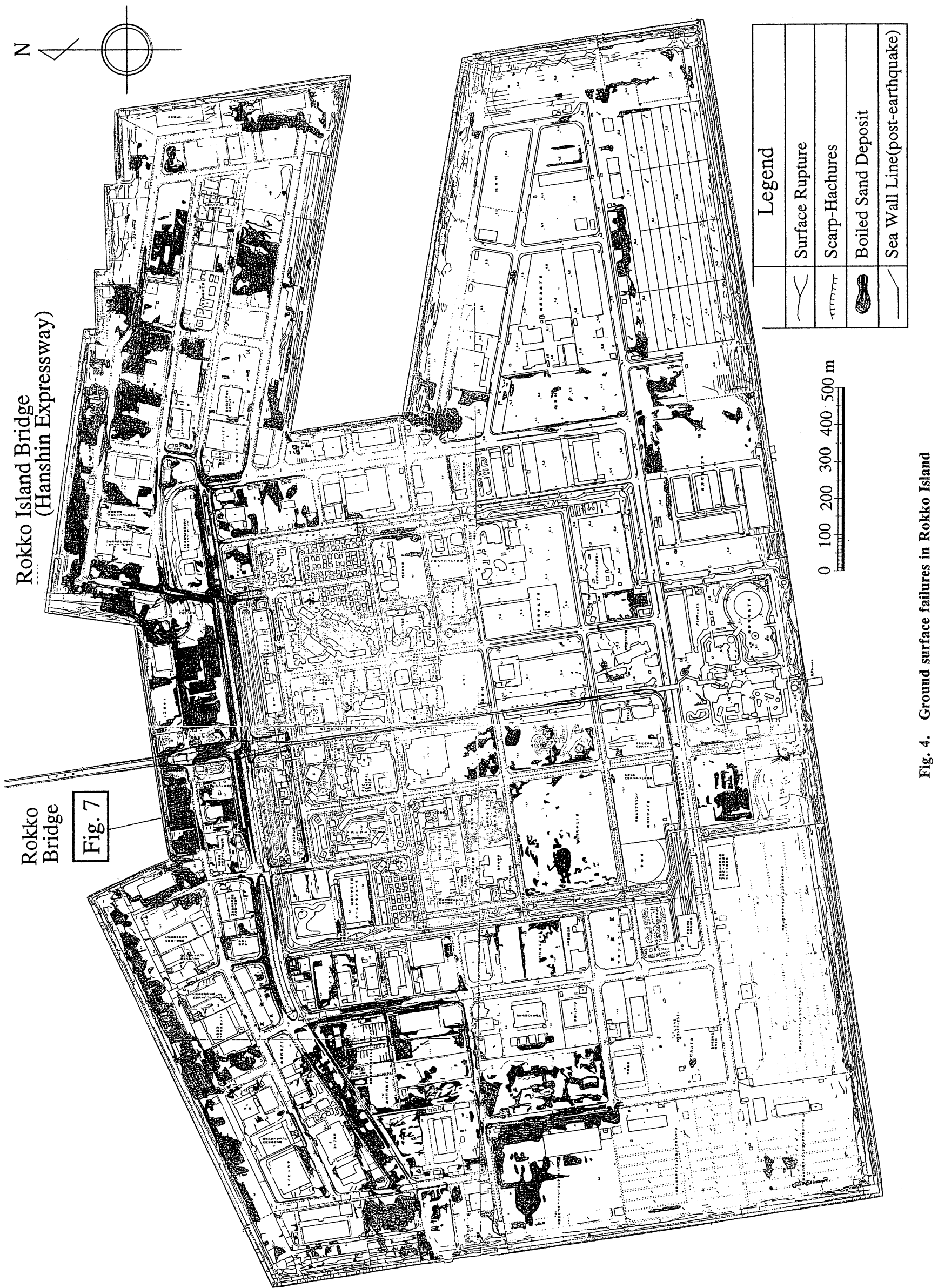




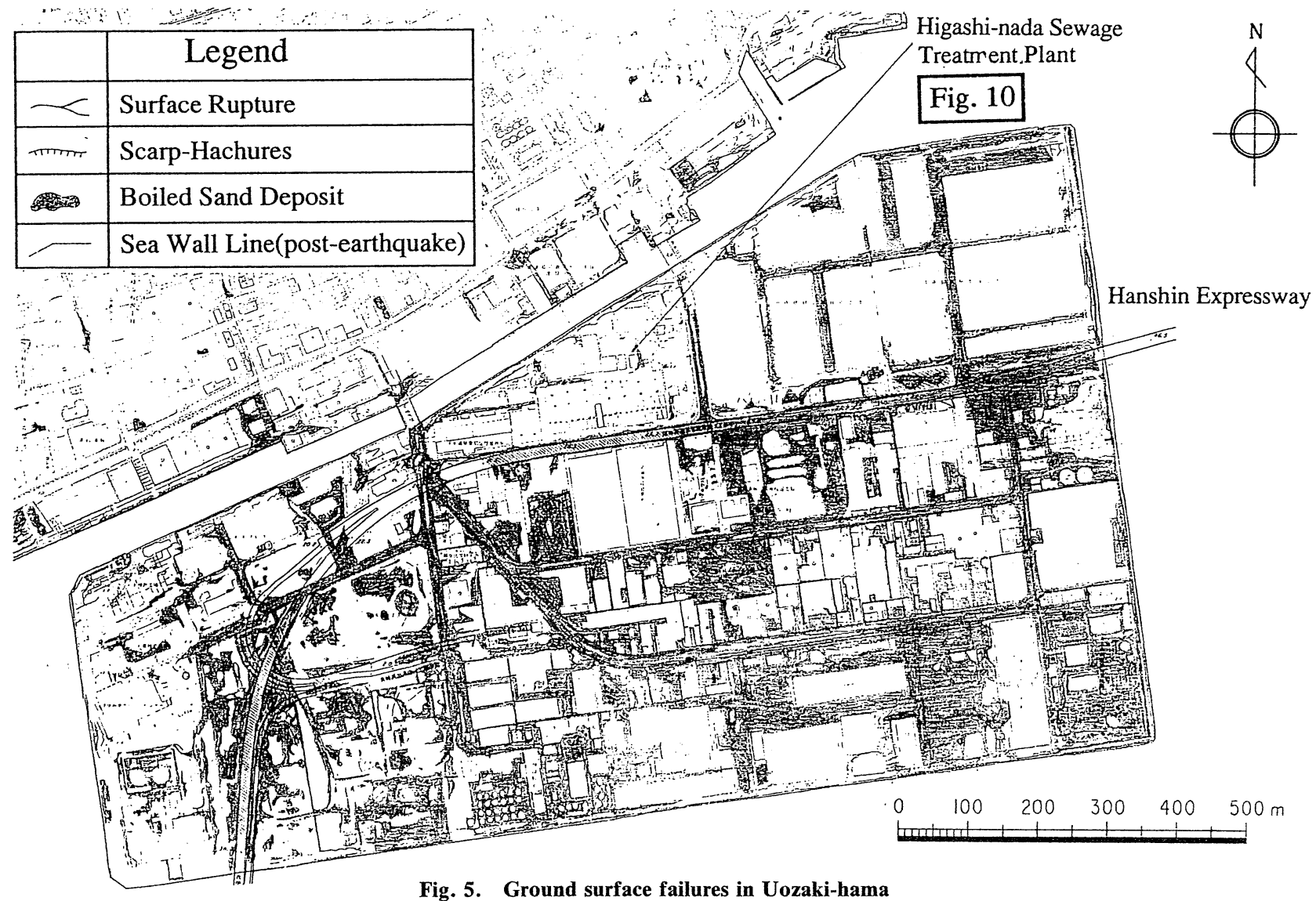

Fig. 5. Ground surface failures in Uozaki-hama

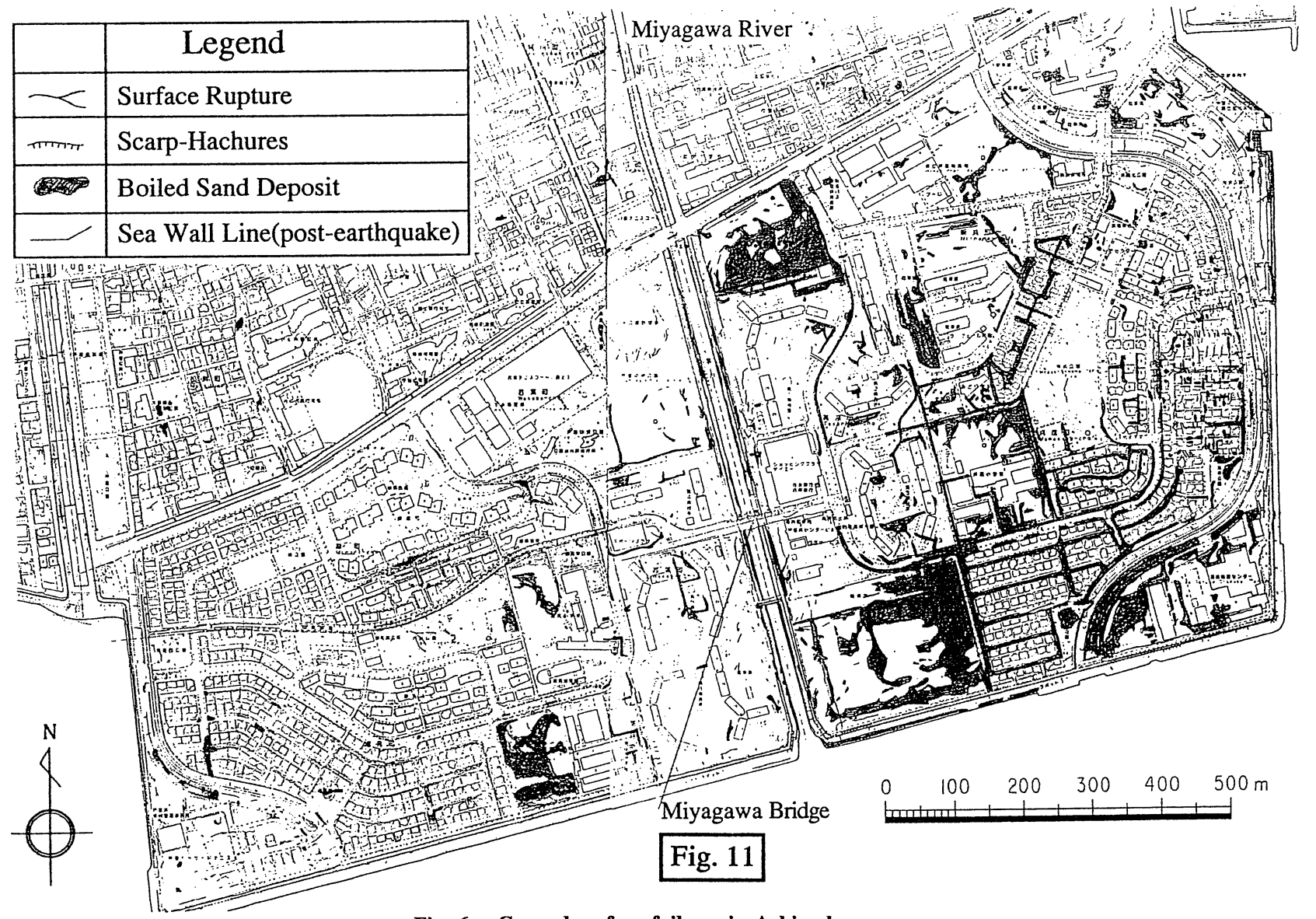

Fig. 6. Ground surface failures in Ashiya-hama 
earthquake depends on scale reduction of the aerial photographs, human errors in reading the coordinates etc. The accuracy of aerial survey before the earthquake was estimated to be $\pm 24 \mathrm{~cm}$ horizontally and $\pm 27 \mathrm{~cm}$ vertically, while it was estimated as $\pm 23 \mathrm{~cm}$ horizontally and $\pm 46 \mathrm{~cm}$ vertically after the earthquake. Attention should be paid to the fact that these accuracies were estimated as a standard variation of residual errors. The maximum error in this measurement is $\pm 56 \mathrm{~cm}$ horizontally and $\pm 54 \mathrm{~cm}$ vertically before the earthquake, while \pm 84 $\mathrm{cm}$ horizontally and $\pm 98 \mathrm{~cm}$ vertically after the earthquake. It should be noted, therefore, that errors of such magnitude can occurred at some observation points. The accuracy of the surveys after the earthquake can be improved, however, if the coordinates of the standard control points are measured with greater accuracy in the future.

The accuracy of liquefaction-induced ground displacements is given as a root-mean square of the accuracies before and after the earthquake, and is estimated as \pm 33 $\mathrm{m}$ horizontally and $\pm 53 \mathrm{~cm}$ vertically.

Relative displacements between two observation points, namely ground strains are very important to investigate the failure process for buried pipelines. The accura- cy of relative displacements depends on the scale reduction of the aerial photographs. The accuracy of the relative displacement (in the horizontal direction) is $7.6 \times 10^{-6} \mathrm{~m}$ before the earthquake and $12.8 \times 10^{-6} \mathrm{~m}$ after the earthquake in the scale of the aerial photos. The accuracies of the relative displacement before and after the earthquake were estimated to be $9 \mathrm{~cm}$ and $11 \mathrm{~cm}$, respectively. Therefore, the accuracy of the relative displacement is estimated to be $14 \mathrm{~cm}$ as a root mean square of the above two standard variations.

The area where the ground displacements was measured consists of most of the reclaimed land shown in Fig. 2. The complete results of the measurements are included in Hamada et al. (1995). In this report, the authors indicate some typical examples of the ground displacements and the related damage to buried pipelines and foundations.

\section{Liquefaction-induced Ground Displacement and its Related Damage}

Figure 7 shows the ground displacements of the northern part of Rokko Island where severe liquefaction occurred. The sea wall along the north end of the island moved toward the sea for a maximum $3.5 \mathrm{~m}$, and settled

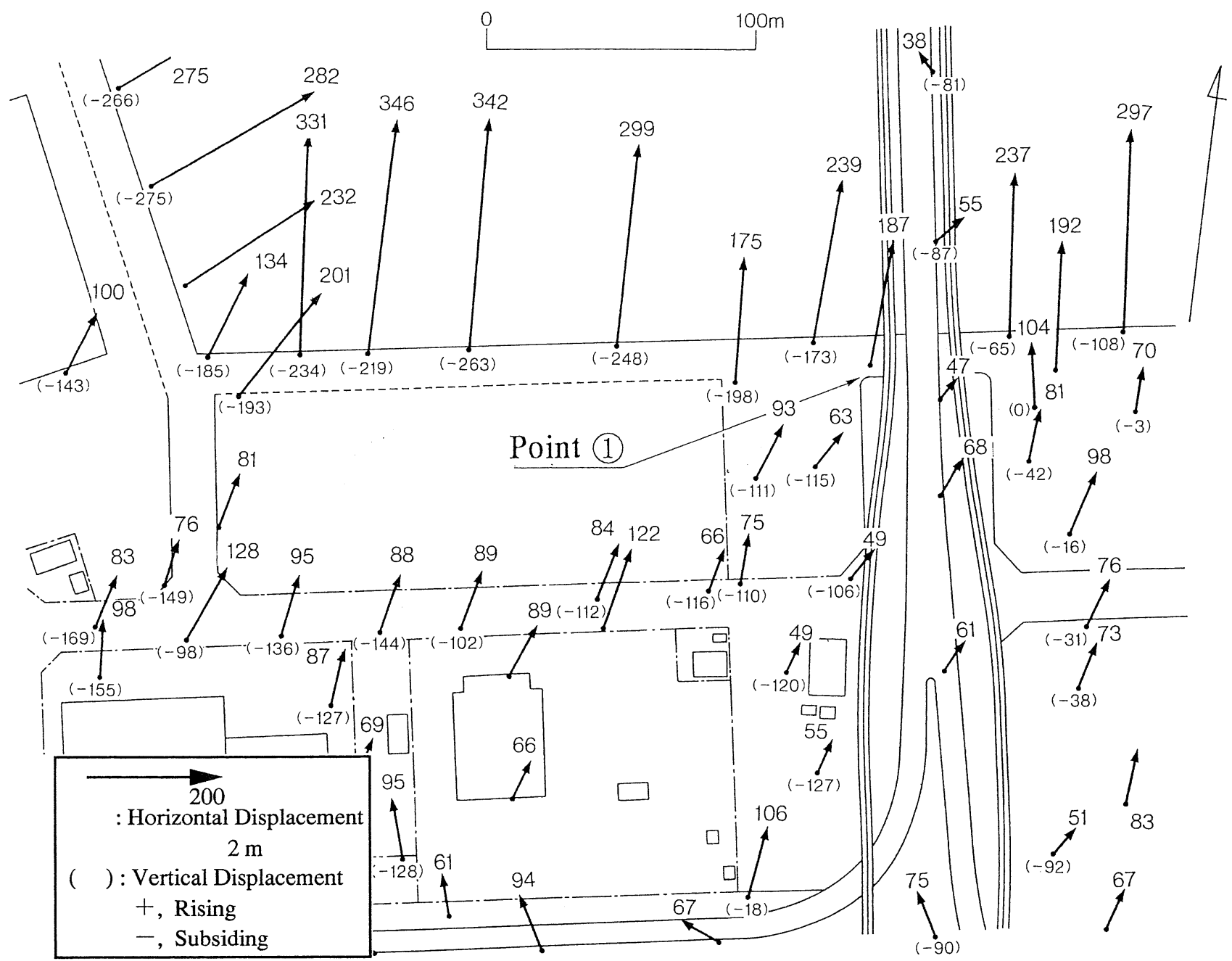

Fig. 7. Liquefaction-induced ground displacement on northern part of Rokko Island 


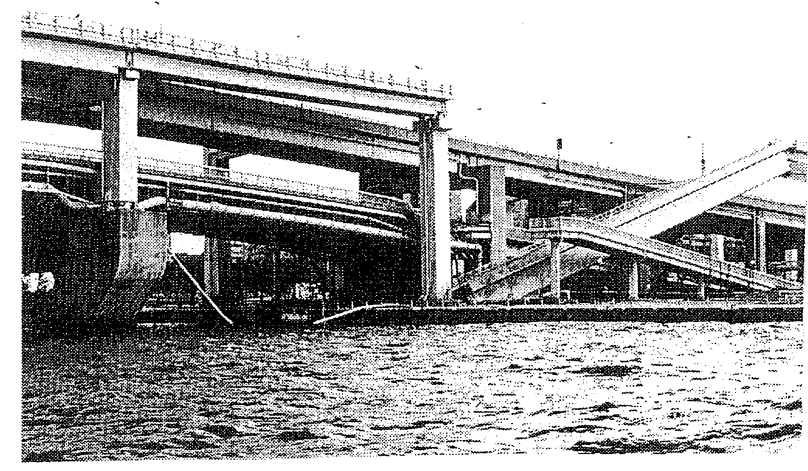

Photo. 2. Bridge girder dropped due to ground displacement (Point (1) in Fig. 7)

more than $2.0 \mathrm{~m}$. At Point (1) in the figure a simply supported steel girder for the Rokko Liner bridge dropped from the pier as shown in Photo. 2, because the pier moved toward the sea due to the large displacement of the surrounding subsoil mass. According to the onground survey which was conducted by Kobe City after the earthquake, the top of the concrete caisson of the foundation displaced about $80 \mathrm{~cm}$ toward the sea.

It should be noted that the ground about $100 \mathrm{~m}$ far from the sea wall also moved toward the sea with a distance of about $1 \mathrm{~m}$. It can be seen that a large movement of the sea wall affected a wide area behind it because of the liquid-like flow behavior of the liquefied soil.

The soil conditions in this area are shown in Fig. 1 as a part of the soil profile cross section $\mathrm{G}_{-} \mathrm{G}^{\prime}$. The soil fill with a thickness of about $15 \mathrm{~m}$ is considered to have liquefied. The ground surface inclined slightly toward the Rokko Bridge (to the north), which coincided with the direction of the ground displacements.

Figure 8 shows the ground displacements in the north area of Port Island. The quay wall line moved toward the north for a maximum distance of about $4 \mathrm{~m}$, and also settled. At Point (2) in the figure, the concrete pier of Kobe Bridge inclined slightly towards the sea due to the movement of the surrounding ground, as shown in Photo. 3. The pier was supported on pile foundations the tips of which reached into a firm Pleistocene soil layer.

A welded steel pipe with a diameter of $60 \mathrm{~cm}$ for a water trunk line was ruptured at point (3) in the figure as shown Photo. 4. A zone heat affected from welding was ruptured due to a large ground strain caused by the liquefaction. In addition, at Points (4) and (5), concrete piles were broken vertically at the top of the pile as shown in Photos. 5 and 6, due to an excessive bending moment caused by large ground displacements. It should be noted that the building at Point (5) although located about $100 \mathrm{~m}$ from the sea wall, had its foundation piles broken due to the ground displacement.

The soil conditions in this area are shown in Fig. 1 as a part of the soil profile cross section E-E'. The soil fill with a thickness of about $10 \mathrm{~m}$ is also considered to have

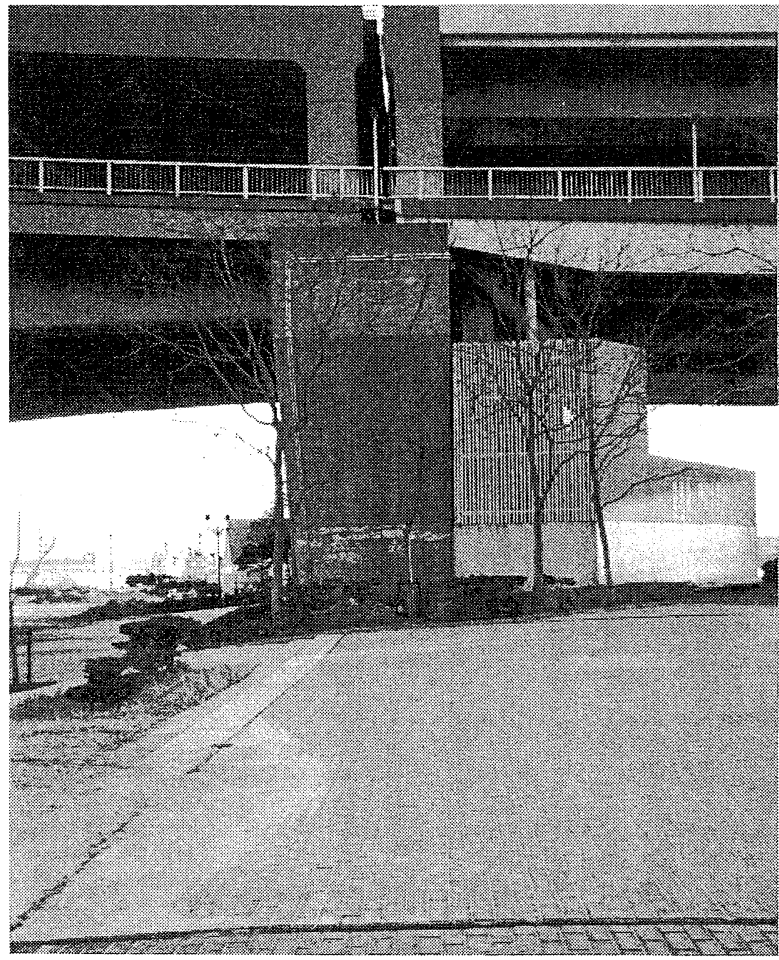

Photo. 3. Slightly inclined concrete pier due to ground displacement (Point (2) in Fig. 8)

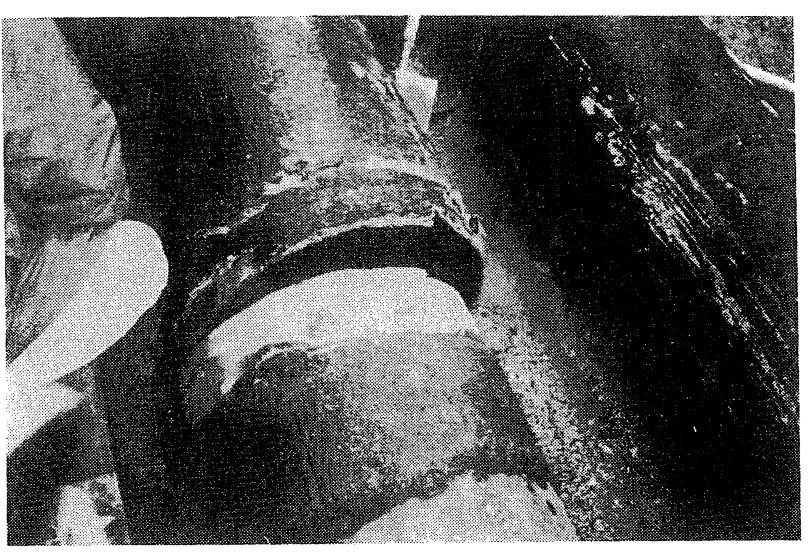

Photo. 4. Rupture of welded steel pipe for water trunk line (Point (3) in Fig. 8)

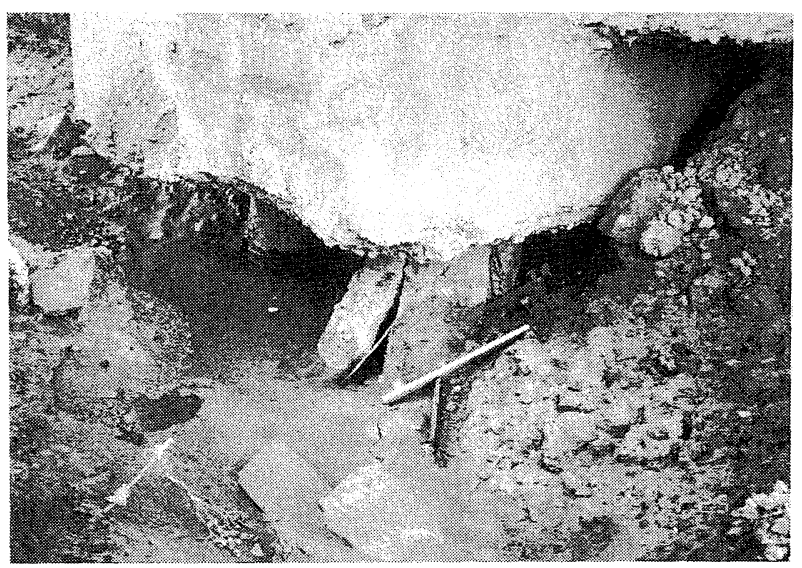

Photo. 5. Concrete pile breakage (Point (4) in Fig. 8) 


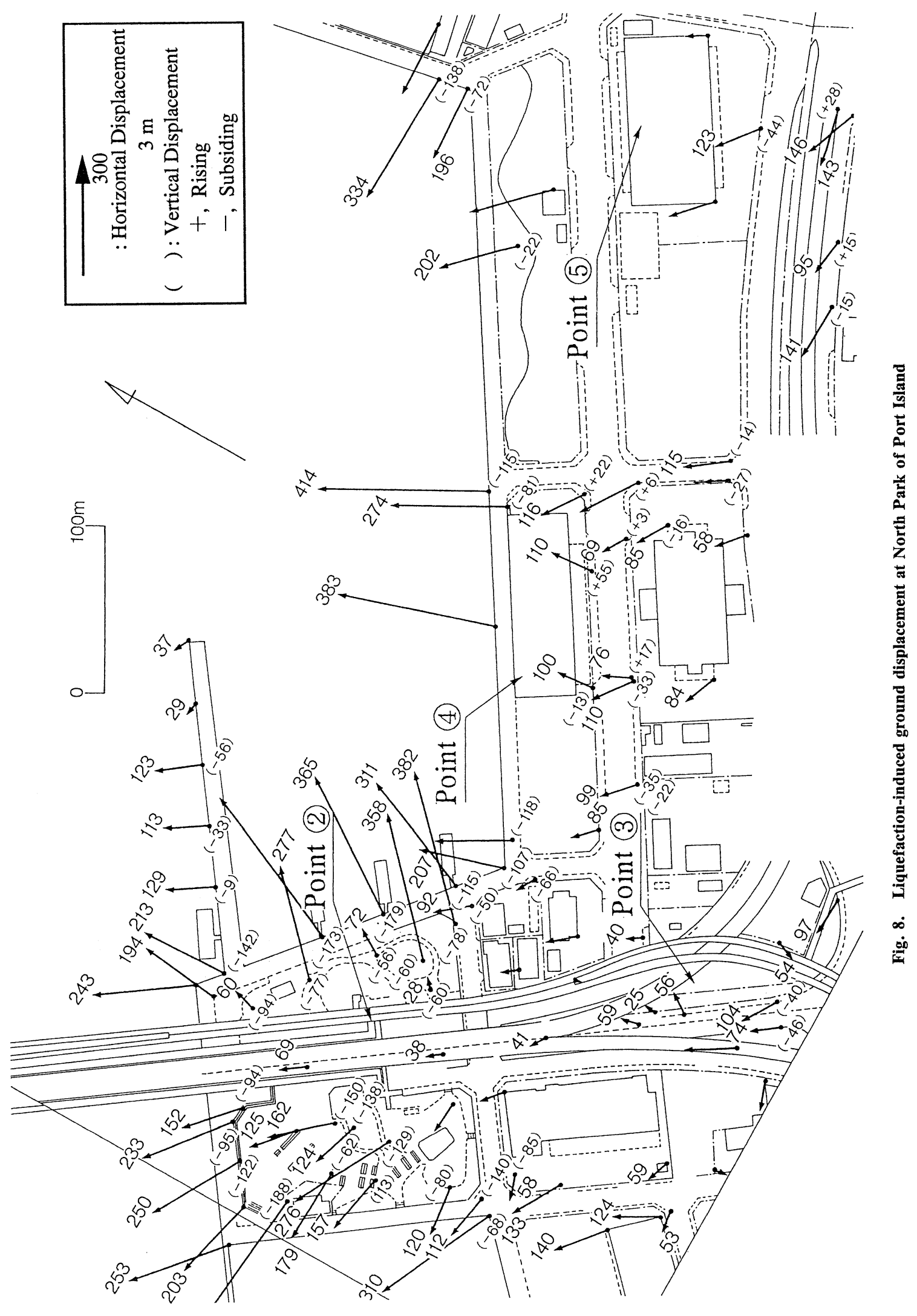




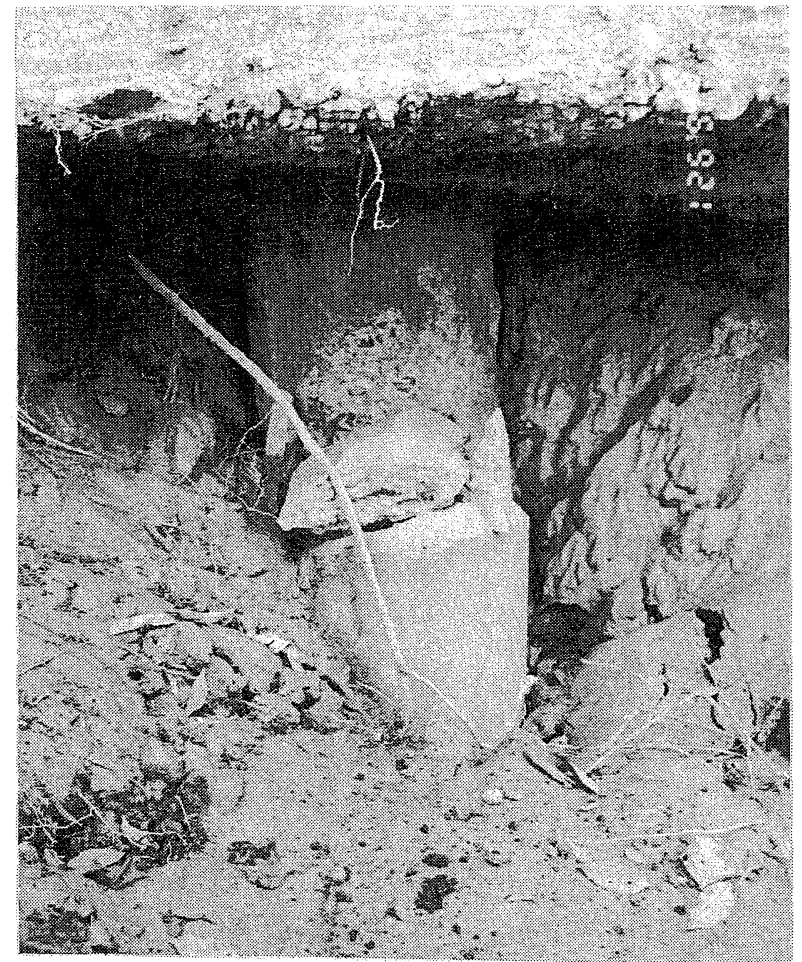

Photo. 6. Concrete pile breakage (Point (5) in Fig. 8)

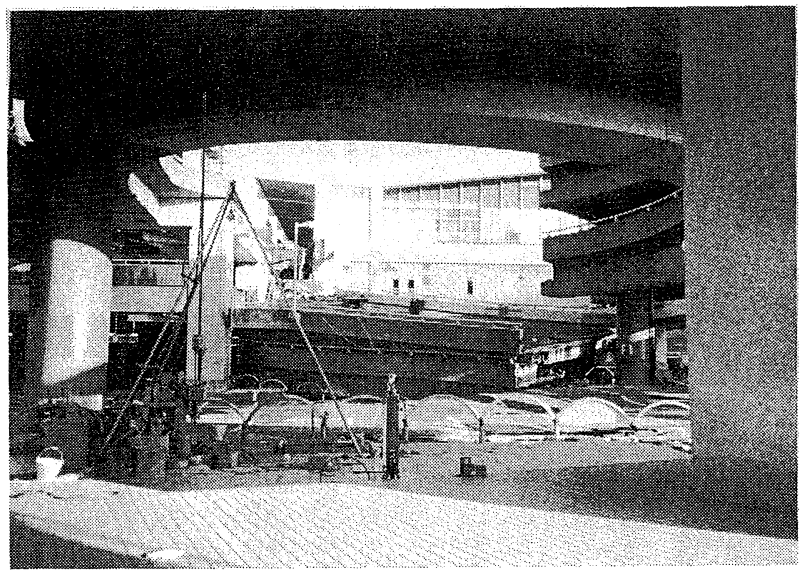

Photo. 7. Bridge girder dropped due to ground displacement (Point (6) in Fig. 9)

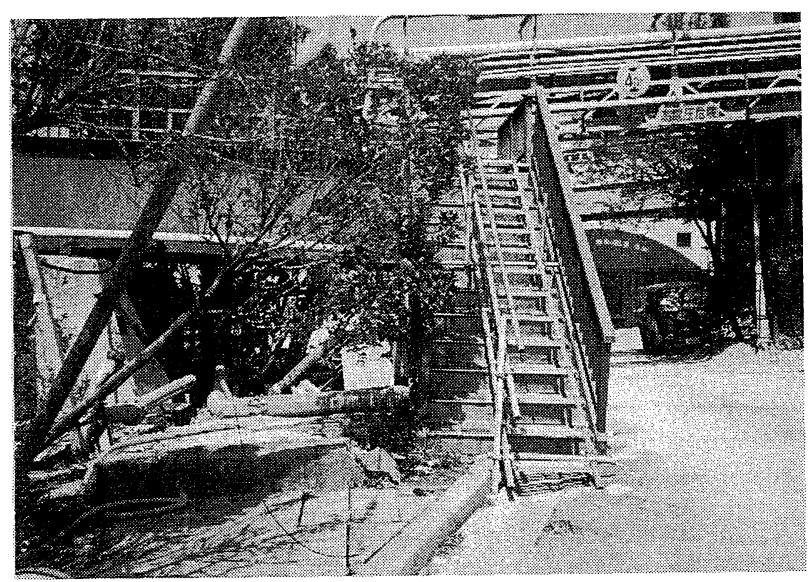

Photo. 8. Movement of foundation for stairs of over-canal bridge at Uozaki-hama (Point (2) in Fig. 10)

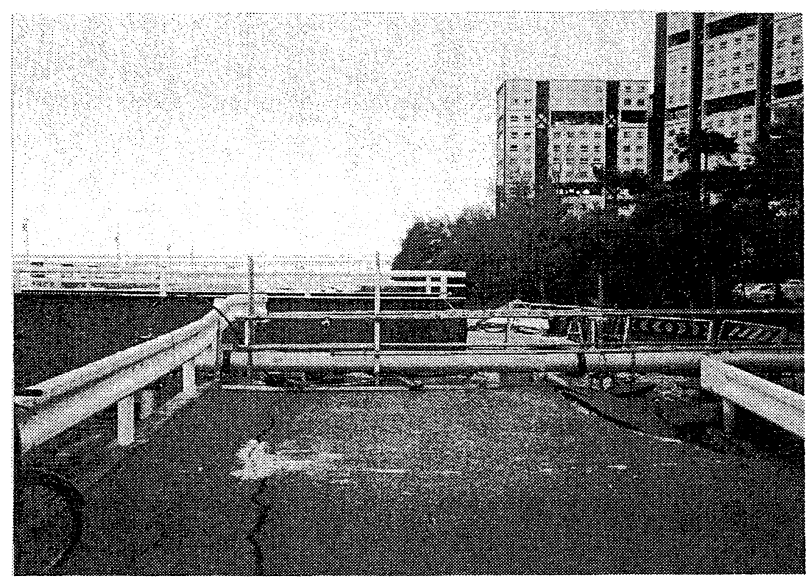

Photo. 9. Movement of river bank at Ashiya-hama (Point (8) in Fig. 11)

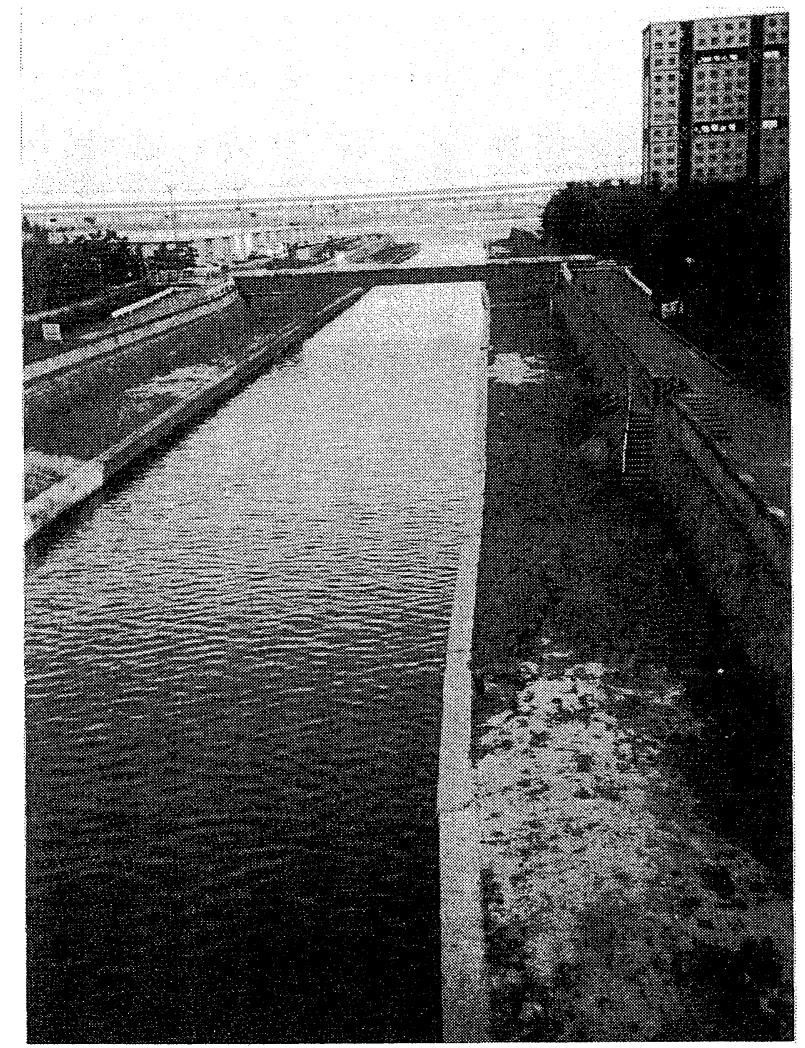

Photo. 10. River bank after movement of ground at Ashiya-hama

liquefied.

Figure 9 shows the ground displacement along Pier No. 4 of the Kobe Wharf. The ground was displaced towards the sea for a maximum distance of about $3.0 \mathrm{~m}$. At Point (6), a two-story high steel bridge girder dropped due to extensive movement of the pier, as shown in Photo. 7. According to the aerial survey, the end of the noncollapsed girder moved about $90 \mathrm{~cm}$ toward the sea and this movement was considered as the direct cause of the collapse of the girders. Along Pier No. 4, a concrete conduit with a cross section $4.8 \mathrm{~m} \times 3.0 \mathrm{~m}$ was buried, but it was reported that the concrete at the joints was slightly separated, and the inside of the conduit was flooded. In 


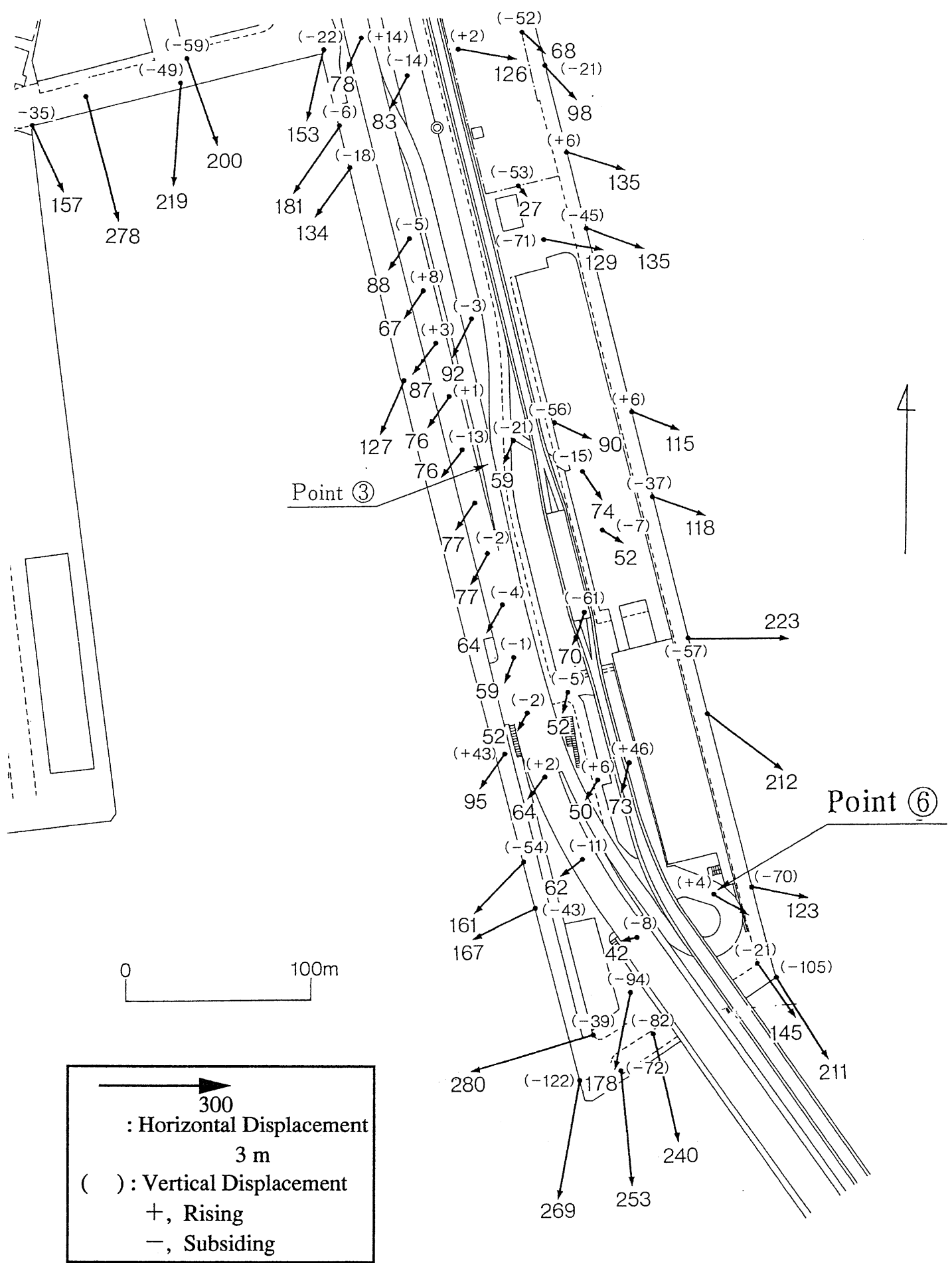

Fig. 9. Liquefaction-induced ground displacement at pier No. 4 of Kobe Wharf

addition, a concrete caisson for the foundation of the Kobe Bridge moved toward the sea and inclined due to ground surfase and subsoil movement.

Severe liquefaction also occurred in the reclaimed lands on the mainland side such as Uozaki, Fukae etc., and resulted in damage to buried pipelines and buildings. Figure 10 shows the measured ground displacements in Uozaki-hama, where a sewage treatment plant was extensively damaged due to liquefaction and ground displace- ment. Along the canal north of the plant, both banks moved toward the water $1 \sim 2 \mathrm{~m}$. Photograph 8 shows the conditions at Point (7) in Fig. 10 where the foundation of a stair of a bridge over the canal was displaced about $2.0 \mathrm{~m}$ due to the movement of the surrounding ground. In the sewage treatment plant, the concrete piles of the buildings were broken and a concrete conduit was largely separated at joints due to the ground movement. The soil conditions in this area are shown in Fig. 1 as a 


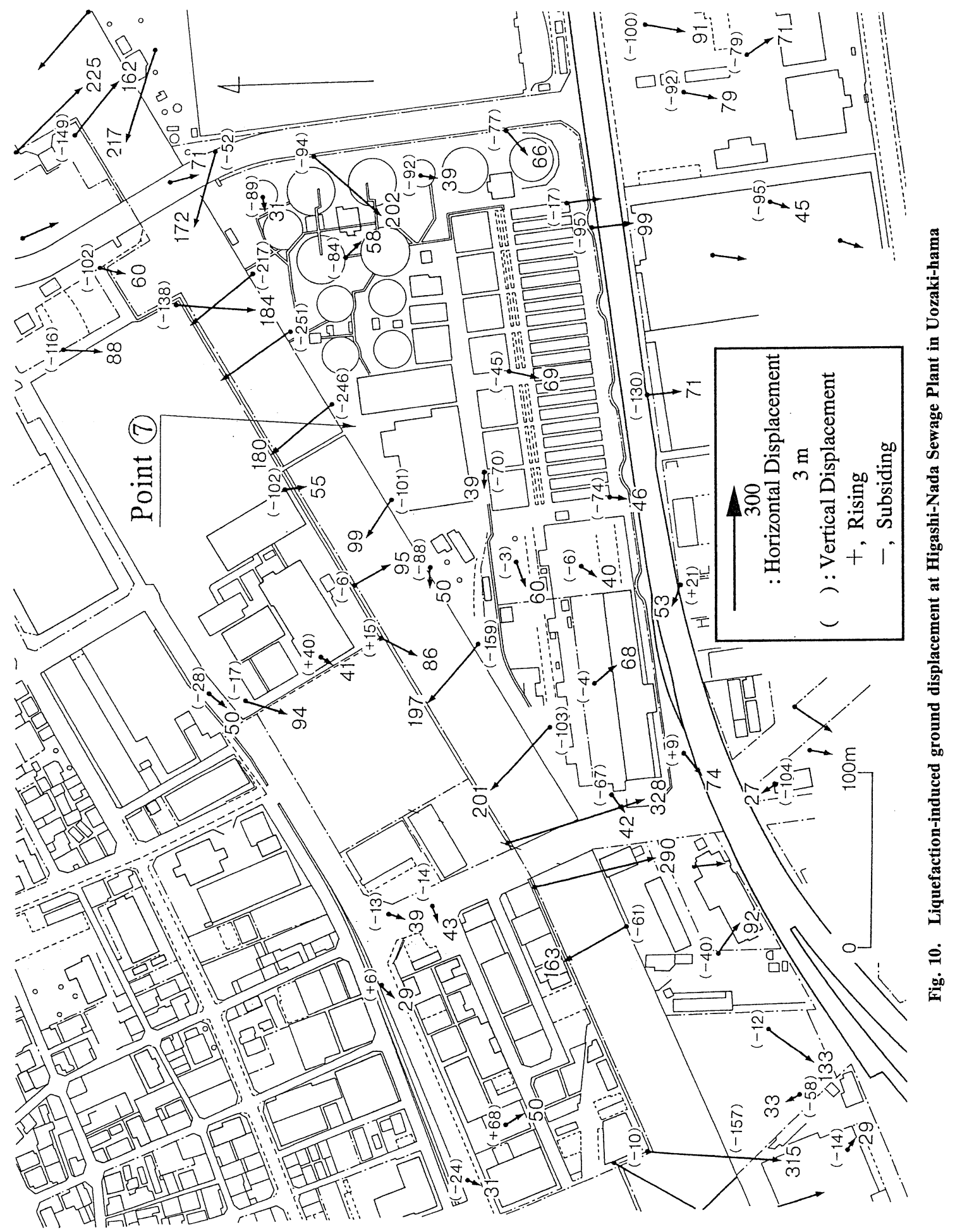


part of section D-D'. The soil fill as thick as more than $10 \mathrm{~m}$ liquefied.

Figure 11 also shows an example of large ground displacement in the reclaimed area on the mainland side. Both banks of the Miya-gawa River in Ashiya-hama moved towards the center of the river about $1 \sim 2 \mathrm{~m}$. Photograph 9 shows that a steel girder of a bridge over the river extends over the road on the river bank at Point (8) in Fig. 11. This suggests that the river bank moved toward the water. Photograph 10 shows the river bank after the earthquake and it should be noted that the line of the river bank was maintained mostly straight even after a movement of about $2 \mathrm{~m}$ and the river bank did not collapse. It can be assumed therefore that the river bank moved on the underlying liquefied soil, which flowed toward the river.

\section{CONCLUSIONS}

The authors conducted a survey of the liquefaction-induced ground failures and displacements caused by the Hyogoken-Nambu earthquake in Kobe and neighboring cities using pre- and post-earthquake aerial photographs. A summary of the principal results of the survey is given

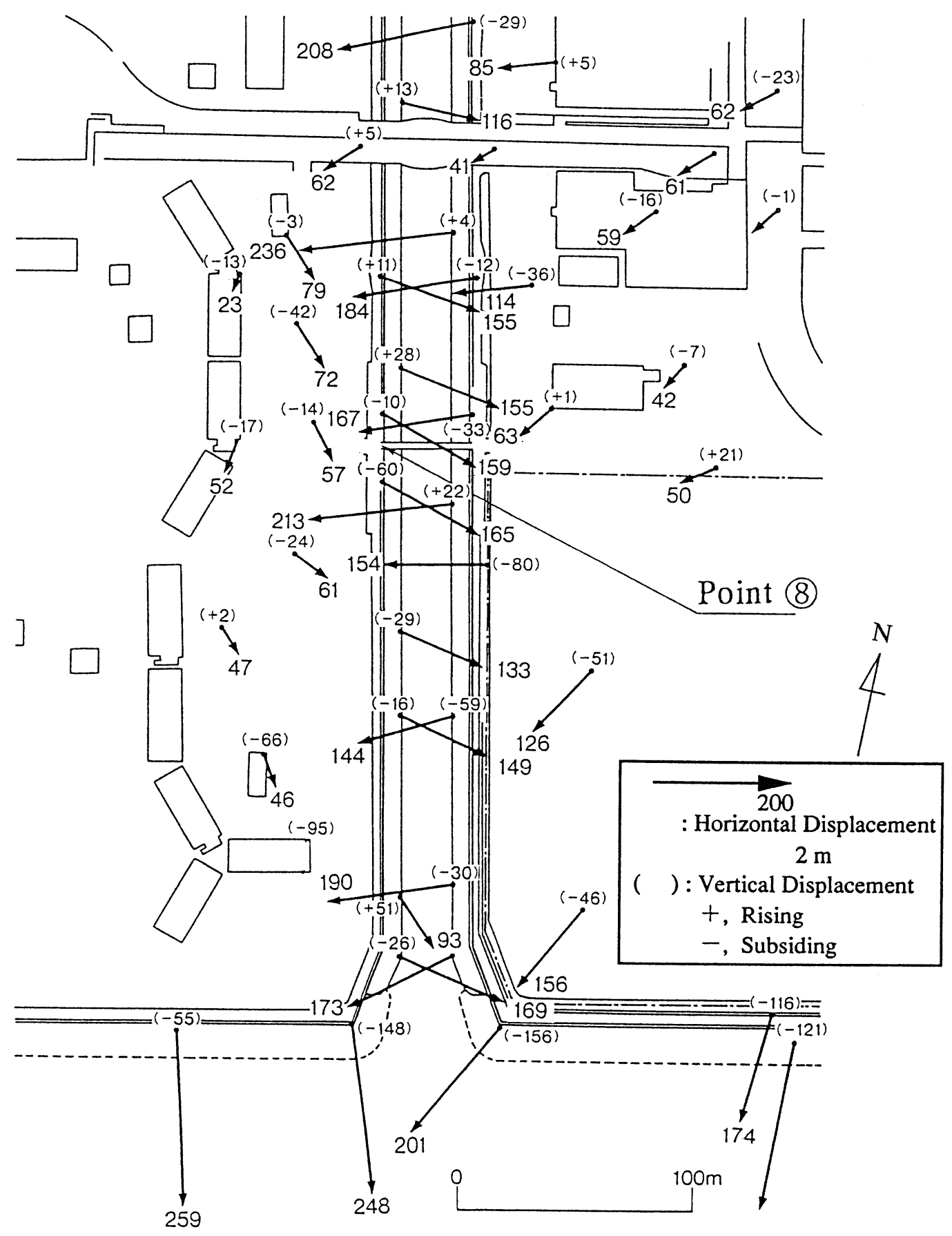

Fig. 11. Liquefaction-induced ground displacement at Ashiya-hama (See Photo. 1) 
below:

1) Soil liquefaction and liquefaction-induced ground failures occurred in huge areas along Osaka Bay extending from Suma-ku, Kobe City to the mouth of the Yodogawa River, in Osaka.

2) Most of the soil liquefaction occurred in land areas recently reclaimed from the sea including two man made islands, however minor liquefaction was also observed in old reclaimed soils and natural subsoils.

3) The soil liquefaction induced large ground displacements in the horizontal direction along the waterside of the reclaimed lands, resulted in serious damage to buried lifeline facilities and foundations of structures.

4) It seems that recent fills without soil improvement suffered extensive soil liquefaction, while older fill areas and natural subsoil profiles performed well. In addition, the materials used for the fills were also affected to the level of liquefaction.

\section{ACKNOWLEDGMENT}

The authors wish to express their gratitude to those who have provided valuable assistance in the preparation of this paper. Special thanks are extended to Mr. I. Yasuda of Hasshu Corporation, who contributed extensively to measurement of liquefaction-induced ground displacements by using pre- and post-earthquake photographs.
Gratitude is also extended to the officials of Hyogo Prefectural Government, Kobe City Government and Hanshin Highway Corporation, and the people of Geotop and Fudo Construction Company, who provided valuable data on soil conditions.

\section{REFERENCES}

1) Hamada, H., Isoyama, R. and Wakamatsu, K. (1995): The Hyogoken-Nambu (Kobe) Earthquake, Liquefaction, Ground Displacement and Soil Condition in Hanshin Area, Association for Development of Earthquake Prediction, The School of Science and Engineering, Waseda University and Japan Engineering Consultants Co., Ltd.

2) Japanese Society of Soil Mechanics and Foundation Engineering (JSSMFE) ed. (1974): Local Soils in Japan, JSSMFE, pp. 85-141 (in Japanese).

3) Kobe City (1980): The Ground of Kobe (in Japanese).

4) Miyanaga, S. and Takeyama, S. (1991): "The history of the reclamation in Kobe”, Tsuchi-to-Kiso, JSSMFE, Vol. 39, No. 1, pp. 42-45 (in Japanese).

5) Private communication with the Enterprise Agency of Hyogo Prefecture (1995).

6) Private communication with the Housing Public Corporation of Hyogo Prefecture (1995)

7) The Third Port and Harbor Bureau, Ministry of Transport (1967): The Record on Construction of Maya Wharf (in Japanese).

8) Toyo Corporation (1987): The History of Naruo-Hama Project (in Japanese). 